DOI: https://doi.org/10.24867/09GI14Raickovic

\title{
UTICAJ ORGANIZACIONOG UČENJA NA ZADOVOLJSTVO ZAPOSLENIH U ORGANIZACIJI
}

\section{IMPACT OF ORGANIZATIONAL LEARNING FOR EMPLOYEE SATISFACTION WITHIN AN ORGANIZATION}

\author{
Tanja Raičković, Fakultet tehničkih nauka, Novi Sad
}

\begin{abstract}
Oblast - INŽENJERSKI MENADŽMENT
Kratak sadržaj - Cilj ovog istraživanja jeste razumevanje značaja organizacionog učenja kao faktora motivacije $i$ u kojoj meri ono utiče na zadovoljstvo zaposlenih $u$ organizacijama u Republici Srbiji. Da bi se istražilo koliko se ovaj nematerijalni oblik motivacije vrednuje $i$ primenjuje, u radu je utvrđen nivo motivacije zaposlenih, nivo zadovoljstva poslom i uticaj organizacionog učenja na zadovoljstvo zaposlenih.
\end{abstract}

Ključne reči: Motivacija, Zadovoljstvo poslom, Organizaciono učenje, Organizacija

Abstract - The aim of this research is to understand the importance of organizational learning as a motivation factor, and to what extent it affects the satisfaction of employees within organizations in the Republic of Serbia. In order to investigate how much this intangible form of motivation is valued and applied, the paper determines the level of employee motivation, job satisfaction, and how organizational learning affect employee satisfaction.

Keywords: Motivation, Employee Satisfaction, Organizational Learning, Organization

\section{UVOD}

U okruženju koje je danas dinamično, pojedinci u organizaciji predstavljaju primarni resurs. Upravljanje ljudskim resursima postalo je jedno od vodećih segmenata savremenih organizacija. Intelektualni kapital značajno utiče na rast i razvoj organizacije, odnosno na njeno ispunjenje unapred postavljenih ciljeva. Zadovoljenjem potreba pojedinaca, kako materijalnih, tako i nematerijalnih, organizacija obezbeđuje njihovu lojalnost, angažovanost i spremnost da joj pomogne u ostvarivanju konkurentske prednosti.

Ukoliko je organizacija upoznata sa potrebama svojih zaposlenih, na adekvatan način će planirati i sprovoditi strategiju motivacije za koju se odluči i koja će dovesti do toga da su pojedinci u njoj zadovoljni uslovima rada, organizacionom kulturom i klimom.

\footnotetext{
NAPOMENA:

Ovaj rad proistekao je iz master rada čija mentorka je bila dr Leposava Grubić - Nešić, red. prof.
}

\section{POJAM MOTIVACIJE}

Motivacija predstavlja proces pokretanja aktivnosti čoveka, usmeravanje njegove aktivnosti na određene objekte $\mathrm{i}$ koordinaciju te aktivnosti radi postizanja određenih ciljeva [1].

Motivacija znatno utiče na zadovoljstvo poslom, zbog čega top menadžment treba da se fokusira na različite stimulative koji mogu doprineti efektivnom i efikasnom izvršavanju posla. Motivacioni pokretači su ključni za uspeh poslovnog sistema. Organizacija treba da teži ka razvijanju osećaja pripadnosti svojih zaposlenih, ka stvaraju zajedništva, oslobađajući potencijal svakog svog člana kroz materijalne i nematerijalne faktore motivacije.

\subsection{Materijalni faktori motivacije}

Primena materijalnih, odnosno finansijskih faktora motivacije predstavlja složen model motivacije koji je usmeren na obezbeđenje i zadovoljavanje egzistencijalnih potreba pojedinaca i njihovih finansijskih očekivanja.

Materijalni faktori se mogu podeliti na dve grupe [2]:

1. Direktni materijalni dobici koje zaposleni dobija u novcu (plata, novčani bonusi i stimulacije, finansijske nadoknade za inovativnost, finansijske stimulacije za ostvarenu dobit preduzeća);

2. Indirektni materijalni dobici (stipendije za školovanje i stručno usavršavanje, studijska putovanja, plaćeni slobodni dani, mogućnost korištenja službenog automobila, životno osiguranje, novčane nagrade za određene praznike, plaćen godišnji odmor...).

\subsection{Nematerijalni faktori motivacije}

Nematerijalni faktor motivacije treba da zadovolji psihološke i socijalne potrebe pojedinca, poput osećaja zajedništva, razvoja i priznavanja sposobnosti, statusa, saradnje i sigurnosti. Ukoliko se organizacije posvete ovim faktorima motivacije, zaposleni će zadovoljiti svoje lične potrebe $\mathrm{i}$ ispuniti sopstvene ciljeve što će povećati njihovo zadovoljstvo i na taj način se poistovetiti sa svojim poslom i organizacijom.

Postoje različiti nematerijalni motivatori koje organizacije sprovode [3]:

- dizajniranje posla;

- organizacija posla;

- uključivanje zaposlenih; 
- $\quad$ pohvale i priznanja;

- organizovanje stručnog usavršavanja.

\section{ZADOVOLJSTVO ZAPOSLENIH POSLOM}

Uspešne organizacije na zaposlene gledaju kao na primarni razvojni resurs. Zadovoljstvo poslom treba da se prožima kroz čitavu organizaciju, a na njega utiče angažovanost organizacije, odnosno u kojoj meri ona postiže i održava zadovoljstvo zaposlenih. Naglasak se stavlja na aktivno upravljanje njihovim potencijalima, jer sistematično planiranje karijere predstavlja jedan od značajnih segmenata upravljanja ljudskim resursima.

Zadovoljstvo poslom je disciplina koja se može definisati kao kognitivna, afektivna i evaluativna reakcija pojedinca na svoj posao i ona predstavljaju tri osnovne komponente zadovoljstva poslom [4]:

- $\quad$ kognitivna komponenta - predstavlja verovanje pojedinca da poseduje celokupno znanje o predmetu stava;

- afektivna komponenta - predstavlja emotivno osećanje pojedinca prema poslu;

- evalutivna komponenta - predstavlja predispoziciju da se deluje u određenom pravcu (ocenu posla).

\subsection{Faktori koji utiču na zadovoljstvo poslom}

Mnogobrojna istraživanja ukazuju na činjenicu da je zadovoljstvo poslom važan faktor motivacije i postignuća zaposlenih, što se direktno odražava na individualne, organizacione $\mathrm{i}$ poslovne performanse organizacije $\mathrm{u}$ celini [5].

Faktori koji utiču na zadovoljstvo poslom, mogu se podeliti u dve kategorije [5, 6]:

- organizacioni faktori zadovoljstva poslom;

- lični faktori zadovoljstva poslom.

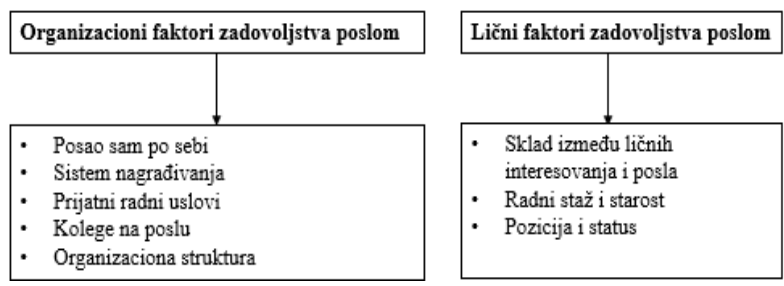

Slika 1. Podela faktora koji utiču na zadovoljstvo poslom

\subsection{Merenje zadovoljstva poslom}

Merenje zadovoljstva poslom je merenje reakcije na posao, odnosno koliko je pojedinac u organizaciji zadovoljan, odnosno nezadovoljan uslovima rada, organizacionom klimom. Do sada je razvijeno nekoliko tehnika, a neke od njih su [7]:

- rejting skale i upitnici - sadrže pitanja koja omogućavaju pojedincima $u$ organizaciji da iskažu svoje reakcije na posao. Najpopularniji upitnik je indeks opisa posla, Minesota upitnik o zadovoljstvu, koji je i korišćen u ovom radu;

- tehnika kritičnog incidenta - koristi se za ocenjivanje zadovoljstva zaposlenih svojim poslom. Pojedinac opisuje one događaje koji se odnose na njegov rad, a koji su po njegovom mišljenju posebno zadovoljavajući, odnosno nezadovoljavajući;

- intervjui i sastanci konfrontacije - predstavljaju razgovore sa zaposlenima koji se vode licem u licem. Važno je da se oni vode u atmosferi u kojoj ne vlada strah kako bi odgovori bili istiniti.

\section{ORGANIZACIONO UČENJE I NJEGOV UTICAJ NA MOTIVACIJU ZAPOSLENIH}

Organizaciono učenje je proces usvajanja novih znanja u organizaciji, kao i usavršavanje i nadogradnja postojećih.

\subsection{Vrste organizacionog učenja}

Postoji više podela kada je reč o vrstama organizacionog učenja, od kojih je najpoznatija podela na $[8,9]$ :

- učenje u jednom krugu;

- učenje u duplom krugu.

Učenje u jednom krugu jeste adaptivno učenje. To podrazumeva učenje u kojem se stiču saznanja i vrše promene samo u okvirima prethodno definisanog skupa pretpostavki koje se dalje ne preispituju. Primenjuje se kada promene u okruženju nisu radikalne i brze [10,11].

Druga navedena vrsta jeste učenje u duplom krugu, odnosno generativno učenje. Kod generativnog učenja se preispituju i menjaju prethodno uspostavljeni standardi i osnovne pretpostavke. Ono podrazumeva i stvaranje novih rutina $u$ organizaciji, ne samo poboljšavanje postojećih. Koristi se kada je dinamičnost okoline velika $[10,11]$.

\subsection{Proces organizacionog učenja}

Autori Pawlowsky, Forslin, Reinhardt su poces organizacionog učenja podelili na pet osnovnih faza [12]:

- identifikacija postojećeg znanja;

- kreiranje ili generisanje novog znanja u organizaciji;

- difuzija postojećeg i novog znanja u organizaciji;

- $\quad$ integracija i modifikacija znanja;

- $\quad$ korišćenje znanja za promenu ponašanja članova organizacije i preduzimanje potrebnih akcija.

Prva faza podrazumeva identifikaciju, odnosno prepoznavanje znanja koje je značajno za organizaciju. Kreiranje novog znanja jeste osmišljavanja ideja i stvaranje inovacija u procesima u organizaciji. Treća faza predstavlja deljenje znanja kroz čitavu organizaciju, i postojećeg i novog. Faza integracije i modifikacije podrazumeva memorisanje, čuvanje organizacionog znanja kako bi bilo svima dostupno, dok peta faza jeste korišćenje znanja za promenu ponašanja članova organizacije.

\subsection{Načini organizacionog učenja}

Postoji nekoliko različitih načina organizacionog učenja koji su u praksi pokazali dobre rezultate. To su [13]: 
Metod refleksije i analize - predstavlja metod pretvaranja implicitnog u eksplicitno znanje i stvaranje novog znanja, koji se naziva još i metod refleksije i analize.

Metod diskusije i konferencije - ovim načinom se stvara novo znanje i prožima kroz čitavu organizaciju, ali i utvrđuje postojeće.

Izveštaji - još jedan od načina jeste pisanje izveštaja koji su takođe značajni za širenje znanja. Izveštaji sa naučnih konferencija su značajni, jer sadrže nova znanja koja mogu pomoći organizacijama pri organizaciji posla i ostvarivanju postavljenih ciljeva.

Priručnici, procedure, uputstva - na osnovu pisanja određenih priručnika, uputstava i procedura, koji treba da budu svima u organizaciji dostupni, zaposleni dele znanje među sobom.

Biblioteke u organizaciji - takođe imaju značajnu vrednost kada je reč o organizacionom učenju. Ukoliko postoji određena baza znanja, članovi organizacije $u$ svakom trenutku mogu da joj pristupe kako bi se sprečio određeni problem.

Benčmarking - jedna od značajnih načina organizacionog učenja, jer podrazumeva da eksperti jedne organizacije obilaze druge kako bi analizirali njihova iskustva pri čemu dolazi do stvaranja novih znanja.

Rotacija zaposlenih - premeštanje zaposlenih sa jedne radne pozicije na drugu može doprineti deljenju znanja kao i pospešiti analitičko razmisljanje.

Mentorstvo - metoda kojom iskusniji član organizacije (mentor) prenosi svoja znanja, veštine i sposobnosti mlađim i manje iskusnim kolegama.

Različiti računarski programi - utiču na usavršavanje postojećeg znanja kod zaposlenih, ali se kreira i novo.

\section{METODOLOGIJA ISTRAŽIVANJA}

\subsection{Predmet i cilj istraživanja}

Predmet istraživanja jesu zaposlena lica bilo kog uzrasta, dok je cilj je razumevanje značaja organizacionog učenja kao faktora motivacije i u kojoj meri ono utiče na zadovoljstvo zaposlenih u organizacijama u Republici Srbiji.

\subsection{Hipoteze istraživanja}

U ovom radu je definisana jedna glavna hipoteza i šest pomoćnih. Sve su potvrđene.

Glavna hipoteza glasi:

(H0): $\mathrm{Na}$ motivaciju i zadovoljstvo poslom deluje organizaciono učenje (nematerijalni faktor).

Pomoćne hipoteze:

(H1): Zadovoljstvo zaposlenih poslom je važno za razvoj organizacije.

(H2): Motivacija zaposlenih je važna za razvoj organizacije.

(H3): Nematerijalni faktor motivacije (organizaciono učenje) se još uvek dovoljno ne vrednuje i primenjuje u organizacijama.
(H4): Organizaciono učenje različito deluje na opštedemografske karakteristike.

(H5): Zadovoljstvo zaposlenih različito deluje na opštedemografske karakteristike.

(H6): Motivacija različito deluje na opštedemografske karakteristike.

\subsection{Metod istraživanja}

Za potrebe ovog rada korišćeni su primarni podaci prikupljeni posredstvom anonimnih anketa koje su kreirane na osnovu unapred istraženog materijala na zadatu temu. $U$ istraživanju je učestvovalo 56 zaposlena lica. Upitnik je prilagođen samoj temi, a nakon probnog istraživanja definisan je kodirani upitnik. Istraživanje je vršeno pomoću Likertove skale stavova.

\subsection{Rezultati istraživanja}

Istraživanje je pokazalo da većini ispitanika nije najznačajniji materijalni faktor motivacije, odnosno novčani stimulativi, stoga bi organizacije trebale da se posvete i drugim motivatorima.

Ispitanici se slažu da su nematerijalni faktori motivacije, pre svega organizaciono učenje, značajni za povećanje njihovog zadovoljstva, iako je istraživanje pokazalo da se u našim organizacijama ono dovoljno ne vrednuje i ne primenjuje.

Lideri organizacija moraju da se posvete ovom vidu motivisanja i da ovakav nematerijalni motivacioni faktor iskoriste u potpunosti. Kada bi se sagledale sposobnosti i mogućnosti zaposlenih i pravilno iskoristile, sigurno bi se postigao veći efekat rada u veoma kratkom periodu.

Analiza je pokazala da nematerijalni oblici motivacije bitno utiču na zaposlene i na njihov rad, pa samim tim i na razvoj organizacije.

\section{ZAKLJUČAK}

Najvažniji segment svake organizacije jeste čovek. Ukoliko organizacija vodi računa o svojim zaposlenima, postići će zadate ciljeve u unapred određenom vremenskom roku, koji će dovesti do kontinuiranog rasta, ne samo organizacije, već i svakog pojedinca iste.

S obzirom na to da današnje promene značajno utiču na poslovanje organizacije, samim tim se javlja i potreba za poboljšanjem struktura unutar nje. To se odnosi i na zaposlene koji moraju biti primarni fokus svakog preduzeća, što je i zadatak top menadžmenta, odnosno sektora Upravljanje ljudskim resursima. Organizacije ne mogu da funkcionišu bez njegovog adekvatnog rada, te je potrebno definisati pravila i procedure koje se odnose na ljudske resurse, kao i zadatke koje se moraju izvršavati kako bi se postiglo što efektivnije obavljanje posla.

Utvrđivanjem uticaja na motivaciju zaposlenih, odnosno šta utiče na povećanje zadovoljstva poslom, rukovodioci organizacije će imati mogućnost da deluju na promenu postojećeg stanja među članovima organizacije, zatim ga 
menjati u slučaju da je to potrebno i na taj način povećati efikasnost svog kolektiva.

\section{LITERATURA}

[1] Rot, N. (1990). Opšta psihologija. Zavod za udžbenike i nastavna sredstva; Beograd.

[2] Jokanović, D. (2015). Ključni aspekti motivacije zaposlenih u preduzećima Bosne i Hercegovine. Master rad; Univerzitet za poslovni inženjering i menadžment; Ekonomski fakultet; Banja Luka.

[3] Cvetković, M. (2016). Nematerijalna i unutrašnja motivacija zaposlenih u savremenim organizacijama. Master rad; Univerzitet Singidunum; Studijski program poslovna ekonomija; Beograd.

[4] Griberg, Dž., Baron, R. A. (1998). Ponašanje u organizacijama. Želnid, Beograd, 157. strana.

[5] Strukan, E. (2018). Efekti liderstva na organizacione $i$ poslovne performanse preduzeća. Doktorska disertacija; Univerzitet u Novom Sadu; Tehnički fakultet; Zrenjanin.

[6] Ivancevich, J. M., Matteson, M. T. (2002). Organizational Behavior and Management. 6th Edition; New York; McGraw - Hill.

[7] Šuković, F., Mihailović, D. (1997). Psihologija organizacije. Beograd; 121. strana.

[8] Argyris, C. (2003). A Life full of Learning. Organization Studies.
[9] Argyris, C., Schon, D. (1978). Organizational Learning. Reading: Addison - Wesley.

[10] Janićijević, N. (2008). Organizaciono ponašanje. Ekonomski fakultet Beograd; Beograd.

[11] Jovanović, V. (2016). Organizaciono učenje kao faktor održivog upravljanja privrednim društvima. Doktorska disertacija; Džon Nezbit Univerzitet Beograd; Fakultet za menadžment; Zaječar.

[12] Pawlowsky, P., Forslin, J., Reinhardt, R. (2003). Practices and Tools of Organizational Learning. Handbook of Organizational Learning \& Knowledge; Oxford University Press; Oxford; p. 779.

[13] Child, J. (2005). Organization: Contemporary principles and Practices. Oxford: Blackwell.

\section{Kratka biografija}

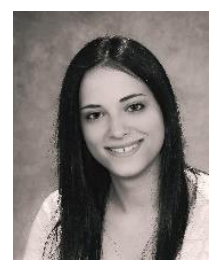

Tanja Raičković rođena je u Subotici 1993. godine. Master rad na Fakultetu tehničkih nauka iz oblasti Inženjerski menadžment odbranila je 2020. godine. 